\title{
Our opinion about the systematic review "Glaucoma y antioxidantes: revisión sistemática" published in this journal
}

\section{Nuestra opinión sobre la revisión sistemática "Glaucoma y antioxidantes: revisión sistemática” publicada en su revista}

\author{
Ilia A. Volchegorskii and Elena V. Tur \\ Chelyabinsk State Medical University, Chelyabinsk, Rusia
}

Dear Dr. Manuel Alejandro Garza León,

We have read with great interest the systematic review by Giaquinta-Aranda, et al. ${ }^{1}$ published in the journal that you direct. We can say that the analytical approach of this work and its methodology have impressed us and initiated great respect.

Unfortunately, after a detailed reading of the full text published, we have found significant contradictions and errors that, in fact, could lead the reader to misunderstandings and damage the reputation of the journal that publishes this systematized review.

At the beginning of the methodology section of the review, it is clearly indicated that, according to the inclusion criteria, «.complete publications of controlled and randomized clinical trials." were included for the study (page 114). On the contrary, on page 117, in the first paragraph, after describing the exclusion criteria, it is stated that: "Articles that met the selection criteria were included. Two authors independently evaluated the search results. First, they examined by title and abstract... When a title of an article seemed relevant, the abstract was evaluated for eligibility. If there was any doubt, the full text of the article was retrieved and evaluated for possible inclusion."

In this regard, it is not entirely clear to us what the inclusion criteria are: "Published full texts", as indicated on page 114, or "selected abstracts that in case of doubt would require reading the full text of the article", as indicated on page 117 below. The reading of this review article, in fact, confirms that the inclusion criteria deviate from what is mentioned on page 114 towards what is indicated on page 117 ("reading the full text in case the abstract generates doubts"). This change of criteria becomes obvious when a publication of ours and of our colleagues ${ }^{2}$ is commented on page 118 compared to the article by Egorov, et al. ${ }^{3}$.

Both publications deal with the therapeutic action of Mexidol, a drug of Russian origin for the treatment of primary open-angle glaucoma (POAG, for its acronym in English). First, we would like to draw your attention to the mistake made when our research is cited in the review of these authors. The error is based on the fact that the influence of Mexidol on changes in the mood of patients with POAG, which is discussed on page 118, does not appear in the article cited in the systematic review (reference 24 of the references). These data do appear in another publication of ours and of our colleagues, in which we conducted a comparative study of the effectiveness of 3-oxypyrodone and succinic acid derivatives in the treatment of POAG ${ }^{4}$. I think you might find interesting reading the full text of this article.

It is unclear to us that when the authors discuss this study on page 118 , why they actually refer to our other publication ${ }^{2}$, which focuses exclusively on the ocular level effects of the most promising derivative of 3-hydroxypyridine and succinic acid (Mexidol), and that 
does not contain any data related to the state of mind of the patients. In addition, we have been quite surprised finding in this review (page 118) the following sentence referring to our publication "....it was not included in the study because it does not describe the intervention group...". On the contrary, the authors (Andrea Giaquinta Aranda, Ana Fernández Araque, Rafael Curbelo Rodríguez, Abel Rojo Aragues) do consider the inclusion in their study of the article by Egorov, et al. ${ }^{3}$, in which the results "... coincide with the data of Volchegorskii, et al...". Given this, I suggest that the versions of both articles should be compared and that you, independently, decide in which of them the group of treated patients is better described and in which the results show more conclusive data. The original full text of both articles can be accessed through the links shown in the references ${ }^{2,3}$.

In addition, I think it is worth adding that, according to the table 2 of this review, in the fourth column of the first row, regarding the article by Egorov, et al., it is mentioned that "the statistical methods used are not explained", which would be one of the exclusion criteria for the systematic review, indicated on page 117.

We also believe that this systematic review has important errors in the references section. Specifically, regarding citations 24 and 26, whose pagination references are erroneous. We would like to emphasize that, besides the pagination references referred to above, there are also inaccuracies in the description of references of relevant publications from the Entrez-PubMed database, where only abstracts translated into English of important publications in Russian language are found. This would confirm an important failure when establishing the inclusion criteria according to what is referred to on page 114 (they analyzed «...complete publications of controlled and randomized clinical trials...»).

\section{References}

1. Giaquinta Aranda A, Fernández Araque A, Curbelo Rodríguez R, Rojo Aragues A. Glaucoma y antioxidantes: revisión sistemática. Revista Mexicana de Oftalmología. 2017;91:112-21.

2. Volchegorskii IA, Tur EV, Solyannikova OV et al. The influence of water soluble antioxidant agent (mexidol) on optic nerve and bloodflow velocity in ocular and orbital arteries in patients with primary open-angle glaucoma. Vestnik Oftalmologii. 2012;128(4):35-41. Disponible en: https://www.mediasphera.ru/issues/vestnik-oftalmologii/2012/4/downloads/ ru/030042-465x201246. Consultado el 20 de julio de 2017.

3. Egorov EA, Gvetadze AA, Davydova NG. Antioxidant agents in neuroprotection treatment of glaucoma. Vestn Oftalmol. 2013:129(2):67-9. Disponible en: https://www.mediasphera.ru/issues/vestnik-oftalmologii/2013/2/downloads/ru/030042-465X2013214. Consultado el 20 de julio de 2017.

4. Volchegorskii IA, Tur EV, Solyannikova OV, et al. Effectiveness of 3-oxypyridine and succinic acid derivatives in complex treatment of primary-open-angle glaucoma. Eksp Klin Farmakol. 2012;75(7):20-6. Disponible en: http://ekf.folium.ru/index.php/ekf/article/view/184/161. Consultado el 20 de julio de 2017. 